\title{
The Impact of Socialization on Collaborative Learning Method in e-Learning Management System (eLMS)
}

\author{
https://doi.org/10.3991/ijet.v14i20.10992 \\ Zahraa Abed Aljasim Muhisn ( $₫$ ) \\ Al-Qasim Green University, Al Qasim, Iraq \\ zahraa.a@uogasim.edu.iq \\ Mazida Ahmad, Mazni Omar, Sinan Adnan Muhisn \\ Universiti Utara Malaysia, Sintok, Malaysia
}

\begin{abstract}
The rapidly increasing use of information and communication technology (ICT) in the academic community allows learners to access information and academic content anywhere at anytime. e-Learning Management System (eLMS) is one of the popular tools that are increasingly being used in higher education institutions to support and manage teaching and learning. This empirical study was thus conducted to investigate the impact of e-learning on the socialisation among students in Iraq. The sample comprised of 109 undergraduate students from College of Information Technology at a public university in Iraq, all of whom were active eLMS users. The participants took part in a survey, the results of which indicated that knowledge can be effectively transferred from lecturer to students via eLMS, which motivates students to share knowledge with peers through socialisation process, which is one of the critical aspects of Knowledge Management (KM).
\end{abstract}

Keywords - Knowledge management (KM), Socialization, e-Learning Management System (eLMS), Tacit Knowledge, Explicit Knowledge

\section{Introduction}

The rapidly increasing use of information and communication technology (ICT) in the academic community changes how knowledge is created, stored, organised, disseminated, and managed [1]. The practice of ICT in all forms of education is enforced and continuous technological advancement in use of ICT at has replaced traditional learning schemes with modern eLearning solutions with more flexibility and freedom for students to learn at their own pace and time with the use of computer, tablets, mobile, and internet facility [2].

According to [3], electronic learning (e-learning) is an ICT application aimed at improving access to resources that facilitate education and learning. [4] pointed out that e-Learning Management System (eLMS) as an e-learning platform / system is increasingly being adopted by academic institutions to help facilitators and students gain access to online services and educational materials. 
As Knowledge Management (KM) provides a way to capitalise on intellectual capital, it can also be used in Institutions of Higher Learning (IHLs)[5]. Moreover, it is recognized that IHLs work in the field of knowledge, as they engage in the creation and dissemination of knowledge, and are increasingly exposed to market pressures in a similar way to other companies.

\section{$2 \quad$ Related Works}

\subsection{Review of e-learning management system (eLMS)}

Learning is defined as the process of interaction between learners, learning content, teacher, and learning peers, and its effectiveness relies on the success of close interaction among these elements [1]. e-learning can be defined as learning using electronic means. In addition, a study [6] described it as acquiring skills and knowledge using electronic technologies, such as WANs, LANs, and computer-based approaches. Elearning has emerged as an educational support tool for building an ICT-based learning environment [7].

According to [8], e-learning has not only become more effective but also more rapid due to the emergence of the Internet, which can be used to access a wide range of learning tools, and allows the users (teachers and students) to communicate through discussion forums, e-mail and social networks. Thus, this concept can be used as a major learning method or as a common way to the face-to-face class.

According to [9], many benefits can be derived from online learning platforms, as they promote innovation skills and enhance thinking, thus enabling students to take part in sharing knowledge and sharing open societies without restrictions on space and time by exchanging thoughts, sharing ideas and exploring information together.

e-Learning Management System (eLMS) is defined as the technology that based on the web that can assists with the distribution, monitoring, and evaluation of the learning process [10]. eLMS has recently been recognised as effective in supporting learning opportunities worldwide and provides a means of delivering education and flexibility to higher education institutions [4], [11], [12].

\subsection{Knowledge management}

The Knowledge Management (KM) concept pertains to any practices and processes involved in the creation, capture, acquisition, exchange, and use of knowledge, expertise, and skills [13]. In the context of higher education, KM includes organising and creating organisational knowledge, sharing that knowledge with suitable individuals and appropriate groups, and facilitating the application of that knowledge to achieve institution's goals and missions [14].

According to a study [15], effective KM is now the main driver of new ideas and knowledge for innovation, and is essential for the development of a new services, products and innovative solutions. Based on their study on higher education, a study 
by [16] concluded that KM can be implemented successfully in public universities in Malaysia.

More than two decades ago, [17] proposed a knowledge management model that classifies knowledge into tacit and explicit knowledge. Socialisation is one of the critical aspects of KM. This is especially true in eLMS, which motivates students to share knowledge with their peers.

\subsection{Socialisation in eLMS}

Socialisation process involves transferring lecturers' tacit knowledge to individuals, groups, and the entire organisation to create new knowledge [17]-[19]. Socialisation can take place in IHLs during classes, where lecturers use experiences to impart knowledge to students in the form of new thoughts, inspiration, and discussions [20].

Socialisation refers to social interactions and transactions [21], [22] that comprise of three dimensions, namely structure, relative, and cognitive [23]. According to [22], the structure dimension is divided into physical (such as brainstorming and discussion) and online (such as email and forum) forms. The relative dimension refers to the relationships among individuals that have been formed previously, while the cognitive dimension pertains to social interactions among members of an organisation. [24] further categorised the social interaction in online environment into synchronous and asynchronous. According to the authors, synchronous transmission involves audio and videoconferencing, and the asynchronous transmission provides email and forum services.

In an earlier study, [25] outlined three categories of social boundaries, denoting them as human-human, human-object, and human-place. These three social interaction dimensions are coupled with the first two categories of social boundaries involving face-to-face or online discussions to accelerate social interactions and transactions among individuals who already know each other [23]. According to Adam in collaborative learning received a new interpretation in the context of e-learning - collaborative learning supported by the computer [26].

From the industrial perspective, socialisation is referred to as the transfer of experts' tacit knowledge to learners [27]. It can be achieved through mentoring approach, work rotation involving different units, and collaboration [28]. In such contexts, tacit knowledge is formed from the information on the product, services, customers, and operating procedures [29]. Empirical evidence suggests that it is also formed from employees' valuable professional knowledge, which is shared to improve organisational efficiency and effectiveness [30], [31]. In an earlier study, [17] that most Japanese firms emphasise transfer of experts' tacit knowledge into novices' tacit knowledge, aimed at giving the organisation competitive advantage.

In addition, a study by [32], founded that concrete social interaction relationships can improve tacit knowledge among managers. However, [33] challenged the view that socialisation is a process of transferring experts' tacit knowledge, as skills are not necessarily acquired from the experts, but could be obtained through self-learning. On the other hand, [34] argued that socialisation is not necessary for transferring tacit knowledge required for diagnosing disease because the delivery process is asynchro- 
nous, utilising mailing list, not synchronous using video conference. These authors emphasised that socialisation involves time factor, rather than activity factor. However, [35] found that direct communication is an important factor in socialisation, which is further enhanced by a continuous relationship among the group members.

In education, lecturers' tacit knowledge is the expertise transferred in the form of experience and ideas relating to content studied by learners. According to [36], socialisation is implemented through social activities, such as informal meetings between lecturers and learners, consortium, and industrial training. These learning activities involve communication among learners, lecturers, and peers and are aimed at sharing knowledge through synchronous and asynchronous relationships [37]. In addition, according to [9], socialisation is promoted by online discussions, video conferences, social community development, email, virtual classes, interactive learning, wikis, web 2.0 platform, and collaborative writing tools.

Studies by [24], [38] emphasised the importance of communication and collaboration applications, such as email and forums, as these provide opportunities for discussions and Q\&A sessions among lecturers, learners, and peers regarding assignments and curriculum content. These tools can also be used by teachers to share their experiences as well as their beliefs and perceptions [39]. This tacit knowledge transfer and sharing process takes a semester to complete, including fulfilling the coursework requirements.

The discussions presented in the previous paragraph indicate that a strong socialisation process contributes to the quality of the created knowledge [22]. [40] argued that socialisation is a process of sharing ideas and opinions among learners with the aim of solving problems. In fact, [21] suggested that socialisation could be interpreted as a process of social interaction and transaction that leads towards tacit knowledge sharing face-to-face or online, or via both modes through outdoor activities, in classrooms, and eLMS. These interactions can involve learners, lecturers, and peers and are effective in improving learners' tacit knowledge. However, [36] posited that socialisation is not required in educational context because the learner-lecturer interaction is too short for tacit knowledge transfer.

However, authors of the extant studies discussed in the preceding sections focused on activities facilitating socialisation, while neglecting the inter-related elements that form the socialisation process. Moreover, none of these authors assessed the importance of the role of individual experts who transfer tacit knowledge and guide novices in expanding the knowledge into groups and further into the organisation, as outlined in the Socialization-Externalization-Combination-Internalization (SECI) model. Similarly, the effectiveness of the socialisation process has never been measured in the context of lecturers-learners and learners-peers relationships in augmenting learners' tacit knowledge in the forms of independent learning, thinking, and decision making.

eLMS provides forums that support interactions and transactions among lecturers, learners, and peers. Although these interactions and transactions are not in real time, they provide opportunities for learners to interact with lecturers as the alternative for face-to-face meetings in classroom or in other formal settings. Some students feel more comfortable discussing their issues face-to-face with lecturer's than others. 
Hence, online learning simplifies communications in supporting knowledge and experience sharing and collaboration in groups, thus helping avoid the feeling of being neglected [41]. In short, according to available evidence [21], [24], [38], [42] socialisation could be measured in term of extent and frequency of interactions and transactions among learners (novices) and lecturers (experts) through email and forums, as well as among learners and peers, in creating and sharing tacit knowledge.

\subsection{Socialisation in eLMS: Expository technique}

When the expository techniqueis adopted, learning begins with the interaction and transaction between lecturers and learners. In particular, it starts with lecturers explaining to the learners the coursework, including the course notes, assignments, quizzes, and final examination, at the beginning of the semester. In fulfilling the coursework requirements, lecturers teach the curriculum and discuss with the students any remaining issues. Most importantly, learners have the opportunity to interact with lecturer's outside the lecture hours through emails and forums to improve their understanding of the course content. Learners benefit more from the interaction with lecturers compared to other learners (peers) because they depend on lecturers' expertise to master the course content. At the end of the learning process, learners' tacit knowledge is improved and can be shared with lecturers and peers. In short, the faceto-face and online interactions and transactions among lecturers, learners, and peers form the socialisation process in online learning environments.

\subsection{E-Learning and knowledge management}

Knowledge is widely considered the most important asset in any organisation, and thus in the universities and IHLs [5], [16]. According to [43], e-learning has become an important step in the development of KM systems. Study by [44] illustrated some similarities between KM and e-learning, stating that both provide knowledge to thes users, albeit in in different forms. This content can be added, reused, or modified as required for different approaches. They also emphasised that the structure of the system is almost the same for both concepts. For both systems, it is extremely important to provide communication and collaboration facilities, such as forums, email, and chat-rooms, but also other means of communication.

Most IHLs provide e-learning system to their students in the form of forums through which they can communicate with their peers electronically by discussing the learning materials and sharing experiences. Such e-learning systems include personal and scientific information related to individual lecturers, such as the list of academic papers and articles they published, as well as contact information such as e-mail, social networking platforms, and phone number. In addition, they may offer video library featuring lectures given by individual lecturers. 


\section{$3 \quad$ Methodology}

As a part of the present study, a quantitative survey was conducted to understand the impact of e-learning on the socialisation among students in Iraq. According to [45], this is appropriate research design because it allows determining relationships among several factors.

The survey research design was adequate for the present study because pertinent data could be obtained via a set of questionnaires developed by [15] that focus on how knowledge is transferred through the socialisation process among students. The instrument was verified by five experts based on face and content validity. In this study, the sample comprised of 109 undergraduate students from College of Information Technology at a public university in Iraq, all of whom were actively involved in eLMS.

Data collection for this study was carried out during February 2019. The questionnaire distributed to the participating students contained 12 questions focusing on the process of transferring expertise from lecturers to students via emails, forums, and other means. All questions required a response on a five-point Likert scale ranging from 1="Strongly Disagree" to 5="Strongly Agree."

\section{Results and Discussion}

The survey involved 109 respondents, comprising of 39 males and 70 females. The majority of the students were between 19 to 23 years old.The gathered data was analysed using Statistical Package for Social Science (SPSS). The reliability of the instruments was 0.852 . It can be noted that the average score was 3.56 with $\mathrm{SD}=$ .62990 , Table 1 summarises the results of the descriptive statistics analysis.

Table 1. Descriptive Statistics

\begin{tabular}{|c|c|c|c|c|c|c|c|c|c|c|}
\hline \multicolumn{3}{|c|}{ Questions } & \multirow{2}{*}{\begin{tabular}{c|}
$\begin{array}{c}\text { Stronly } \\
\text { Disagee }\end{array}$ \\
14 \\
\end{tabular}} & \multirow{2}{*}{\begin{tabular}{|c|} 
Diagree \\
12 \\
\end{tabular}} & \multirow{2}{*}{\begin{tabular}{|c|c|}
$\begin{array}{c}\text { Do not } \\
\text { agree } \\
\text { neither } \\
\text { disagree }\end{array}$ \\
28 \\
\end{tabular}} & \multirow{2}{*}{$\begin{array}{c}\text { Agree } \\
19 \\
\end{array}$} & \multirow{2}{*}{\begin{tabular}{c|}
$\begin{array}{c}\text { Strongly } \\
\text { agree }\end{array}$ \\
36 \\
\end{tabular}} & \multirow{3}{*}{$\begin{array}{l}\text { Mean } \\
3.47\end{array}$} & \multirow{3}{*}{$\begin{array}{c}\begin{array}{c}\text { Std. } \\
\text { Devia- } \\
\text { tion }\end{array} \\
1.38490\end{array}$} & \multirow{3}{*}{\begin{tabular}{|c|} 
Rank \\
7
\end{tabular}} \\
\hline \multirow{2}{*}{1} & il the lectur- & $\mathrm{N}$ & & & & & & & & \\
\hline & er. & $\%$ & $12.8 \%$ & $11 \%$ & $25.7 \%$ & $17.4 \%$ & $33 \%$ & & & \\
\hline & \multirow{2}{*}{$\begin{array}{l}\text { I always make an ap- } \\
\text { pointment via email. }\end{array}$} & $\mathrm{N}$ & 11 & 23 & 29 & 23 & 23 & \multirow{2}{*}{3.22} & \multirow{2}{*}{1.27916} & \multirow{2}{*}{12} \\
\hline & & $\%$ & $10.1 \%$ & $21.1 \%$ & $26.6 \%$ & $21.1 \%$ & $21.1 \%$ & & & \\
\hline & \multirow{2}{*}{$\begin{array}{l}\text { Lecturer replies directly } \\
\text { to my email }\end{array}$} & $\mathrm{N}$ & 11 & 21 & 23 & 21 & 33 & \multirow{2}{*}{3.40} & \multirow{2}{*}{1.36164} & \multirow{2}{*}{8} \\
\hline & & $\%$ & $10.1 \%$ & $19.3 \%$ & $21.1 \%$ & $19.3 \%$ & $30.3 \%$ & & & \\
\hline \multirow[b]{2}{*}{4} & \multirow{2}{*}{$\begin{array}{l}\text { I use the consultation hour } \\
\text { to communicate with the } \\
\text { lecturer. }\end{array}$} & $\mathrm{N}$ & 15 & 15 & 27 & 19 & 33 & \multirow[b]{2}{*}{3.37} & \multirow[b]{2}{*}{1.39881} & \multirow[b]{2}{*}{9} \\
\hline & & $\%$ & $13.8 \%$ & $13.8 \%$ & $24.8 \%$ & $17.4 \%$ & $30.3 \%$ & & & \\
\hline \multirow[b]{2}{*}{5} & \multirow{2}{*}{$\begin{array}{l}\text { Lecturer participates in } \\
\text { the discussion by giving } \\
\text { his/her comments and } \\
\text { ideas. }\end{array}$} & $\mathrm{N}$ & 8 & 15 & 20 & 27 & 39 & \multirow[b]{2}{*}{3.68} & \multirow[b]{2}{*}{1.29014} & \multirow[b]{2}{*}{4} \\
\hline & & $\%$ & $7.3 \%$ & $13.8 \%$ & $18.3 \%$ & $24.8 \%$ & $35.8 \%$ & & & \\
\hline
\end{tabular}




\begin{tabular}{|c|c|c|c|c|c|c|c|c|c|c|}
\hline \multirow{2}{*}{6} & \multirow{2}{*}{$\begin{array}{l}\text { I get immediate responses } \\
\text { to my question. }\end{array}$} & $\mathrm{N}$ & 11 & 14 & 26 & 28 & 30 & \multirow{2}{*}{3.48} & \multirow{2}{*}{1.29526} & \multirow{2}{*}{6} \\
\hline & & $\%$ & $10.1 \%$ & $12.8 \%$ & $23.9 \%$ & $25.7 \%$ & $27.5 \%$ & & & \\
\hline \multirow[b]{2}{*}{7} & \multirow{2}{*}{$\begin{array}{l}\text { I exchange ideas with my } \\
\text { lecturer during discussion. }\end{array}$} & $\mathrm{N}$ & 8 & 16 & 18 & 28 & 39 & \multirow[b]{2}{*}{3.68} & \multirow[b]{2}{*}{1.29730} & \multirow[b]{2}{*}{3} \\
\hline & & $\%$ & $7.3 \%$ & $14.7 \%$ & $16.5 \%$ & $25.7 \%$ & $35.8 \%$ & & & \\
\hline \multirow{2}{*}{8} & \multirow{2}{*}{$\begin{array}{l}\text { I interact actively with the } \\
\text { lecturer. }\end{array}$} & $\mathrm{N}$ & 7 & 11 & 23 & 38 & 30 & \multirow{2}{*}{3.67} & \multirow{2}{*}{1.17106} & \multirow{2}{*}{5} \\
\hline & & $\%$ & $6.4 \%$ & $10.1 \%$ & $21.1 \%$ & $34.9 \%$ & $27.5 \%$ & & & \\
\hline \multirow[b]{2}{*}{9} & \multirow{2}{*}{$\begin{array}{l}\text { I seek clarification from } \\
\text { the lecturer whenever I } \\
\text { have a question. }\end{array}$} & $\mathrm{N}$ & 13 & 16 & 24 & 25 & 31 & \multirow[b]{2}{*}{3.41} & \multirow[b]{2}{*}{1.35545} & \multirow[b]{2}{*}{11} \\
\hline & & $\%$ & $11.9 \%$ & $14.7 \%$ & $22 \%$ & $22.9 \%$ & $28.4 \%$ & & & \\
\hline \multirow{2}{*}{10} & \multirow{2}{*}{$\begin{array}{l}\text { I exchange ideas with my } \\
\text { friends through group } \\
\text { discussion. }\end{array}$} & $\mathrm{N}$ & 2 & 15 & 18 & 25 & 49 & \multirow[b]{2}{*}{3.95} & \multirow[b]{2}{*}{1.15779} & \multirow[b]{2}{*}{2} \\
\hline & & $\%$ & $1.8 \%$ & $13.8 \%$ & $16.5 \%$ & $22.9 \%$ & $45 \%$ & & & \\
\hline \multirow[b]{2}{*}{11} & \multirow{2}{*}{$\begin{array}{l}\text { I collaborate with my } \\
\text { friends to complete the } \\
\text { assignment given. }\end{array}$} & $\mathrm{N}$ & 9 & 3 & 8 & 39 & 50 & \multirow[b]{2}{*}{4.08} & \multirow[b]{2}{*}{1.17952} & \multirow[b]{2}{*}{1} \\
\hline & & $\%$ & $8.3 \%$ & $2.8 \%$ & $7.3 \%$ & $35.8 \%$ & $45.9 \%$ & & & \\
\hline \multirow{2}{*}{12} & \multirow{2}{*}{$\begin{array}{l}\text { I interact actively with } \\
\text { other students. }\end{array}$} & $\mathrm{N}$ & 18 & 14 & 23 & 18 & 36 & \multirow{2}{*}{3.37} & \multirow{2}{*}{1.46982} & \multirow{2}{*}{10} \\
\hline & & $\%$ & $16.5 \%$ & $12.8 \%$ & $21.1 \%$ & $16.5 \%$ & $33 \%$ & & & \\
\hline \multicolumn{8}{|c|}{ Average Result } & 3.56 & .6299 & \\
\hline
\end{tabular}

The highest average score was recorded for Question 11: "I collaborate with my friends to complete the assignment given," with the mean of 4.08 and standard deviation of 1.17952. This was followed by Question 10: "I exchange ideas with my friends through group discussion" ( $\mathrm{M}=3.95, \mathrm{SD}=1.15779)$. The lowest average score was recorded for Question 2: "I always make an appointment via email" $(\mathrm{M}=3.22$, SD $=1.27916$ ), followed by Question 9: "I seek clarification from the lecturer whenever I have a question" $(\mathrm{M}=3.41$ and $\mathrm{SD}=1.35545)$. The explanations are also demonstrated in Figure 1.

This study shows that knowledge can be effectively transferred from lecturers to students via eLMS, which motivates students to share knowledge with their peers through socialisation process, which is one of the critical aspects of KM, as it helps exchange knowledge. This can be done during classes where lecturers use experience to impart knowledge to students in the form of new ideas, inspiration, and discussions [20]. This finding is supported by [46], who found that the eLMS supported learning environment in higher learning institutions. Students have positive attitude toward eLMS, as they believe that it can help with improving their academic performance by promoting collaboration with peers to complete assignments. They also found it useful for exchanging ideas and interaction with lecturers and colleagues through group discussions, emails, chat, and forums. 


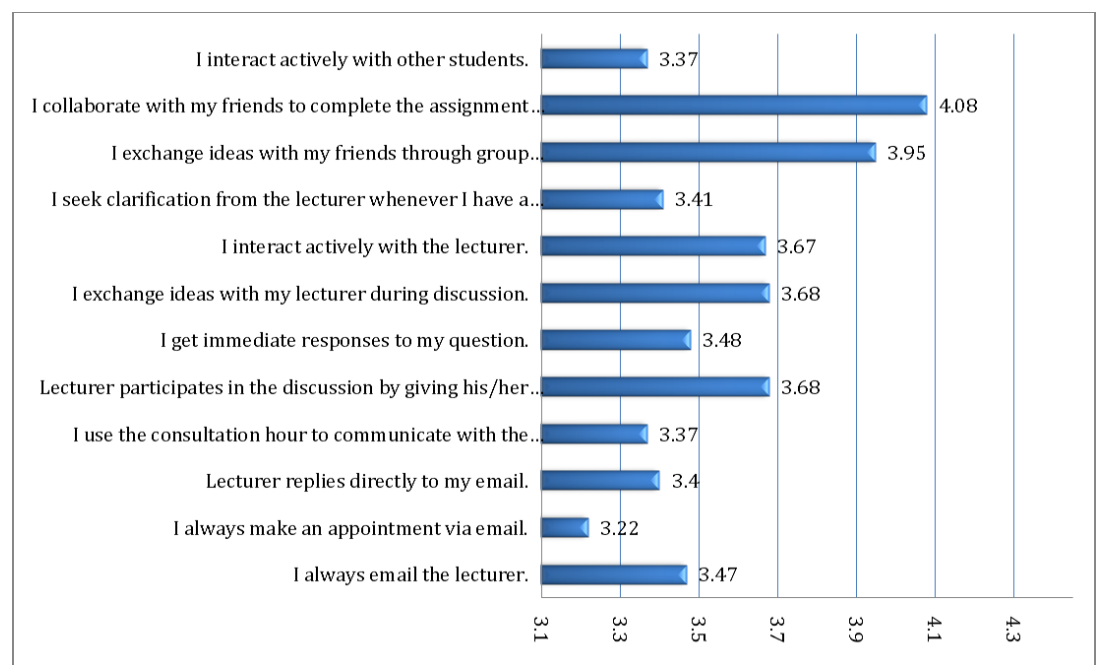

Fig. 1. The responses of sample respondents are about socialization

\section{Conclusion and Recommendation}

Based on the findings reported in this work, students seem to be relying mostly on the lecturers, while failing to use all the available tools for socialisation with peers to create and explore new knowledge. This is likely due to the view that novices can benefit more from interactions with experts. Therefore, it is important for lecturers to play their role at the beginning of learning, allowing students to construct knowledge. When students become more mature and independent, they will likely start to explore knowledge from external sources and interact with their friends.

\section{$6 \quad$ References}

[1] M. S. Islam, S. Kunifuji, M. Miura, and T. Hayama, "Adopting knowledge management in an e-learning system: Insights and views of KM and EL research scholars," Knowl. Manag. E-Learning An Int. J., vol. 3, no. 3, pp. 375-398, 2011. https://doi.org/10.34105/ j.kmel.2011.03.027

[2] Z. A. Solangi, F. Al Shahrani, and S. M. Pandhiani, "Factors affecting Successful Implementation of eLearning: Study of Colleges and Institutes Sector RCJ Saudi Arabia.," Int. J. Emerg. Technol. Learn., vol. 13, no. 6, 2018. https://doi.org/10.3991/ijet.v13i06.8537

[3] R. Boateng, A. S. Mbrokoh, L. Boateng, P. K. Senyo, and E. Ansong, "Determinants of elearning adoption among students of developing countries," Int. J. Inf. Learn. Technol., vol. 33, no. 4, pp. 248-262, 2016. https://doi.org/10.1108/ijilt-02-2016-0008

[4] S. Alharbi and S. Drew, "Using the technology acceptance model in understanding academics' behavioural intention to use learning management systems," Int. J. Adv. Comput. Sci. Appl., vol. 5, no. 1, pp. 143-155, 2014. 
[5] R. Abdullah, M. H. Selamat, A. Jaafar, S. Abdullah, and S. Sura, "An empirical study of knowledge management system implementation in public higher learning institution," Int. J. Comput. Sci. Netw. Secur., vol. 8, no. 1, 2008.

[6] S. Shrestha and J. M. Kim, "Bridging the Gap between E-Learning and Knowledge Management ( KM ): An enhancement of Moodle system by applying KM Functions," Int. J. Sci. Technol., vol. 2, no. 1, pp. 104-111, 2013.

[7] T. Usagawa, "Effectiveness of E-learning Experience through Online Quizzes: A Case Study of Myanmar Students," Int. J. Emerg. Technol. Learn., vol. 13, no. 12, pp. 157-176, 2018. https://doi.org/10.3991/ijet.v13i12.9114

[8] D. Bilinovac, "E-LEARNING AS A TOOL FOR KNOWLEDGE MANAGEMENT," in 14th International Research/Expert Conference "Trends in the Development of Machinery and Associated Technology" TMT 2010, Mediterranean Cruise, 11-18 September 2010, 2010, no. September, pp. 381-384.

[9] S. Chootongchai and N. Songkram, "Design and Development of SECI and Moodle Online Learning Systems to Enhance Thinking and Innovation Skills for Higher Education Learners.," Int. J. Emerg. Technol. Learn., vol. 13, no. 3, 2018. https://doi.org/10.3991/ijet.v13 i03.7991

[10] A. F. M. Ayub, R. A. Tarmizi, W. M. W. Jaafar, W. Z. W. Ali, and W. S. Luan, "Factors influencing students' use a learning management system portal: Perspective from higher education students,” Int. J. Educ. Inf. Technol., vol. 4, no. 2, pp. 100-108, 2010.

[11] E. T. Lwoga and M. Komba, "Antecedents of continued usage intentions of web-based learning management system in Tanzania," Educ. Train., vol. 57, no. 7, pp. 738-756, 2015. https://doi.org/10.1108/et-02-2014-0014

[12] B. Muries and J. Masele, "Explaining electronic learning management systems (ELMS) continued usage intentions among facilitators in Higher Education Institutions (HEIs) in Tanzania,” Int. J. Educ. Dev. using ICT, vol. 13, no. 1, 2017.

[13] W. Q. Qwaider, "Integrated of knowledge management and E-learning system," Int. J. Hybrid Inf. Technol., vol. 4, no. 4, pp. 59-70, 2011.

[14] Q. Geng, C. Townley, K. Huang, and J. Zhang, "Comparative knowledge management: A pilot study of Chinese and American universities," J. Am. Soc. Inf. Sci. Technol., vol. 56, no. 10, pp. 1031-1044, 2005. https://doi.org/10.1002/asi.20194

[15] M. Ahmad, A. Zainol, N. M. Darus, Z. Marzuki, and F. Baharom, "Knowledge Transfer in Software Engineering Education using SECI Model,” Int. J. Inf. Process. Manag., vol. 5, no. 1, pp. 28-38, 2014.

[16] R. A. M. Daud and S. Hassan, "Knowledge management systems for decision makers in public universities Malaysia," in Proceedings of the Knowledge Management International Conference (KMICE'08), 2008, pp. 339-348.

[17] I. Nonaka and H. Takeuchi, "The knowledge creation company: how Japanese companies create the dynamics of innovation." New York: Oxford University Press, 1995.

[18] C. W. Holsapple and K. D. Joshi, "Description and analysis of existing knowledge management frameworks," in Proceedings of the 32nd Annual Hawaii International Conference on Systems Sciences. 1999. HICSS-32. Abstracts and CD-ROM of Full Papers, 1999, p. 15-pp. https://doi.org/10.1109/hicss.1999.772796

[19] G. Muiña, F. Enrique, G. Martín de Castro, and P. López Sáez, "The knowledge-creation process: a critical examination of the," Accessed 24thNovember, 2008, from http//www2.warwick.ac.uk/fac/soc/wbs/conf/olkc/archive/oklc3/papers/id151.pdf, pp. 113. 
[20] C. K. Faith and A. K. Seeam, "Knowledge sharing in academia: A case study using a SECI model approach,” Teach. Writ. Form. Feed. students' Crit. Think. A case study, vol. 9, no. 1, p. 53, 2018.

[21] C. Barreto and M. D’Eredita, "Unraveling expertise and knowledge creation: towards an instance-based model of knowledge (imok)," in 37th Annual Hawaii International Conference on System Sciences, 2004. Proceedings of the, 2004, p. 11-pp. https://doi.org/10.11 09/hicss.2004.1265583

[22] A. Chua, "The influence of social interaction on knowledge creation," J. Intellect. Cap., vol. 3, no. 4, pp. 375-392, 2002.

[23] J. Nahapiet and S. Ghoshal, "Social capital, intellectual capital, and the organizational advantage,” Acad. Manag. Rev., vol. 23, no. 2, pp. 242-266, 1998. https://doi.org/10.5465/ amr.1998.533225

[24] W. Horton and K. Horton, E-learning Tools and Technologies: A consumer's guide for trainers, teachers, educators, and instructional designers. John Wiley \& Sons, 2003.

[25] B. N. Reeves and F. Shipman, "Tacit knowledge: Icebergs in collaborative design," ACM SIGOIS Bull., vol. 17, no. 3, pp. 24-33, 1996. https://doi.org/10.1145/242206.242212

[26] O. Sumtsova, T. Aikina, L. Bolsunovskaya, C. Phillips, O. Zubkova, and P. Mitchell, "Collaborative learning at engineering universities: Benefits and challenges," Int. J. Emerg. Technol. Learn., vol. 13, no. 1, pp. 160-177, 2018. https://doi.org/10.3991/ijet.v13i01. $\underline{7811}$

[27] I. Nonaka, The knowledge-creating company. Harvard Business Review Press, 2008.

[28] S.-W. Chou and M.-Y. He, "Facilitating knowledge creation by knowledge assets," in 37th Annual Hawaii International Conference on System Sciences, 2004. Proceedings of the, 2004, p. 10-pp. https://doi.org/10.1109/hicss.2004.1265584

[29] G. D. Bhatt, "Information dynamics, learning and knowledge creation in organizations," Learn. Organ., vol. 7, no. 2, pp. 89-99, 2000.

[30] A. Smedlund, "The knowledge system of a firm: social capital for explicit, tacit and potential knowledge,” J. Knowl. Manag., vol. 12, no. 1, pp. 63-77, 2008. https://doi.org/10.11 $\underline{08 / 13673270810852395}$

[31] M. Stankosky, Creating the discipline of knowledge management. Routledge, 2005.

[32] C. Dhanaraj, M. A. Lyles, H. K. Steensma, and L. Tihanyi, "Managing tacit and explicit knowledge transfer in IJVs: the role of relational embeddedness and the impact on performance,” J. Int. Bus. Stud., vol. 35, no. 5, pp. 428-442, 2004. https://doi.org/10.10 57/palgrave.jibs.8400098

[33] S. Gourlay, "The SECI model of knowledge creation: some empirical shortcomings," 2003.

[34] M. Shepherd, S. S. R. Abidi, Q. Gao, Z. Chen, Q. Qi, and G. A. Finley, "Information systems and health care ix: accessing tacit knowledge and linking it to the peer-reviewed literature," Commun. Assoc. Inf. Syst., vol. 17, no. 1, p. 40, 2006. https://doi.org/10.17705/ $\underline{1 \text { cais. } 01740}$

[35] M. Smits and A. de Moor, "Measuring knowledge management effectiveness in communities of practice," in 37th Annual Hawaii International Conference on System Sciences, 2004. Proceedings of the, 2004, p. 9-pp. https://doi.org/10.1109/hicss.2004.1265570

[36] C. Kutay and A. Aurum, "Knowledge transformation for education in software engineering.," IJMLO, vol. 1, no. 1, pp. 58-80, 2007.

[37] W. R. J. Baets, Knowledge Management and Management Learning:: Extending the Horizons of Knowledge-Based Management, vol. 9. Springer Science \& Business Media, 2006.

[38] G. Hardaker and D. Smith, "E-learning communities, virtual markets and knowledge creation,” Eur. Bus. Rev., vol. 14, no. 5, pp. 342-350, 2002. 
[39] S. Sharma and O. K. Harsh, "Role of Explicit Knowledge Management and Reuse in Higher Educational Environment," Int. J. Adv. Comput. Sci. Appl., vol. 8, no. 1, pp. 193197, 2017.

[40] H.-M. Huang and S.-S. Liaw, "The framework of knowledge creation for online learning environments," Can. J. Learn. Technol. Rev. Can. l'apprentissage la Technol., vol. 30, no. $1,2004$.

[41] L. Falconer, "Organizational learning, tacit information, and e-learning: a review," Learn. Organ., vol. 13, no. 2, pp. 140-151, 2006. https://doi.org/10.1108/09696470610645476

[42] I. Nonaka and N. Konno, "The concept of 'Ba': Building a foundation for knowledge creation," Calif. Manage. Rev., vol. 40, no. 3, pp. 40-54, 1998.

[43] J. Rowley, "Is higher education ready for knowledge management?," Int. J. Educ. Manag., vol. 14, no. 7, pp. 325-333, 2000.

[44] J. Al-Sadi, B. A. Shawar, and T. H. Sarie, "The Relationship Between Knowledge Management and e-Learning.," in CSREA EEE, 2008, pp. 514-518.

[45] G. G. Gable, "Integrating case study and survey research methods: an example in information systems," Eur. J. Inf. Syst., vol. 3, no. 2, pp. 112-126, 1994.

[46] M. Ahmad, M. Abbas, W. A. J. Wan-Yahaya, and S. N. Abdul-Salam, "Investigating the Knowledge Creation Processes in a Learning Management System (LMS)," in Proceedings of Knowledge Management International Conference, 2012, pp. 652-656.

\section{Authors}

Zahraa Abed Aljasim Muhisn is a lecturer at Al-Qasim Green University, Iraq. She received the BSc. degree in computer science from University of Babylon, in 2010, the MSc. degree in information technology from School of Computing, College of Arts and Sciences, Universiti Utara Malaysia in 2015. Her current research interests include information system development, empirical software engineering and software engineering education.

Mazida Ahmad is a senior lecturer at the School of Computing, College of Arts and Sciences, Universiti Utara Malaysia. She received the BMIS degree from International Islamic University of Malaysia, in 2001, the MSc. degree in software engineering from Universiti Teknologi Malaysia, in 2003, and the Ph.D. degree in knowledge management from Universiti Sains Malaysia, in 2010. Her current research interests include knowledge management, information system development and software engineering education. mazida@uum.edu.my

Mazni Omar is a senior lecturer at the School of Computing, College of Arts and Sciences, Universiti Utara Malaysia. She received the BSc. degree (with honors) in information technology from Universiti Utara Malaysia, in 2000, the MSc. degree in software engineering from Universiti Teknologi Malaysia, in 2002, and the Ph.D. degree in information technology and quantitative sciences from Universiti Teknologi MARA, Malaysia, in 2012. Her current research interests include agile software development, empirical software engineering, software quality and data mining. mazni@uum.edu.my

Sinan Adnan Muhisn holds the BSc. degree in computer science from University of Babylon, in 2005, the MSc. degree in information technology from School of Computing, College of Arts and Sciences, Universiti Utara Malaysia in 2015. His 
Paper-The Impact of Socialization on Collaborative Learning Method in E-Learning Management...

current research interests include information system development, software engineering education, web services applications. sinan_net1@yahoo.com

Article submitted 2019-06-04. Resubmitted 2019-07-14. Final acceptance 2019-07-15. Final version published as submitted by the authors. 